\author{
O. Yildirim*, S. Caglak \\ Yildiz Technical University, Istanbul, Turkey \\ (E-mail: ozgury@yildiz.edu.tr, sumeyraelmaci@gmail.com)
}

\title{
On the Lie symmetries of the boundary value problems for differential and difference sine-Gordon equations
}

\begin{abstract}
In general, due to the nature of the Lie group theory, symmetry analysis is applied to single equations rather than boundary value problems. In this paper boundary value problems for the sine-Gordon equations under the group of Lie point symmetries are obtained in both differential and difference forms. The invariance conditions for the boundary value problems and their solutions are obtained. The invariant discretization of the difference problem corresponding to the boundary value problem for sine-Gordon equation is studied. In the differential case an unbounded domain is considered and in the difference case a lattice with points lying in the plane and stretching in all directions with no boundaries is considered.
\end{abstract}

Keywords: symmetry analysis, partial differential equations, difference equations, boundary value problems.

\section{Introduction}

There are many theoretical and numerical studies on the nonlinear wave equations such as sine-Gordon and Klein-Gordon equations in the literature (see [1-3] and the references given therein). Sine-Gordon equations are of particular interest since they attracted much attention in the recent decades due to the exitance of soliton solutions. Solitons are nonlinear waves and have been used in many mathematical models.

Lie symmetries are one of the most powerful methods in obtaining exact solutions of many partial differential equations (PDEs). Many researchers have been studying this field and publishing articles and books [1-21] which investigate the general theory of these applications. However, there is relatively small number of studies that deal with Lie symmetries of boundary value problems for the PDEs. There are some difficulties in the application of Lie symmetries to boundary value problems (BVPs). In symmetry analysis every symmetry of a BVP must be a symmetry of a given PDE, a mapping of the domain to itself and a symmetry of the boundary data. In general, the prescribed initial or boundary conditions are not invariant under the group transformation of the corresponding PDE.

To the extent of our investigation the study of Lie symmetries of BVPs were first done by V.V. Puknachov [19] and G.W. Bluman [7]. For the theoretical aspects we refer to books [6, 20, 21] In the recent studies R. Cherniha et al. [16, 17] defined a new formula. This formula applies for the invariance of BVPs in a wide range of boundary conditions including free (moving) boundaries and boundaries at infinity.

In the present paper BVPs for nonlinear sine-Gordon equation in the differential and difference forms are investigated. Under the transformation groups boundary curves and boundary conditions of the equations are obtained. The formula for the invariance of BVPs presented by Cherniha [16] is used. The main object of this work is to investigate the invariance of a BVPs for sine-Gordon equation in differential and discrete form under the Lie point symmetries of the corresponding equations. Note that some of the results of this work was presented, without proof, in [4].

\section{Preliminaries}

Symmetry analysis of differential and difference equations

In this section we present the theory and definitions in the Lie symmetry analysis. Let us consider the system of differential equations

$$
F_{\lambda}\left(x, u, u_{1}, u_{2}, \ldots, u_{s}\right)=0, \lambda=1,2, \ldots, m
$$

\footnotetext{
${ }^{*}$ Corresponding author.

E-mail: ozgury@yildiz.edu.tr
} 
where $x \in R^{n}, u \in R^{m}$ and $u_{s}$ is the set of $s$-th partial derivatives. We can write the group of point transformations in the space $(x, u)$ as

$$
G_{r}=\left\{x^{i^{*}}=f^{i}(x, u, a) ; u^{k^{*}}=g^{k}(x, u, a), i=1,2, \ldots, n, k=1,2, \ldots, m\right\} .
$$

Using the power series and expanding the transformations about some neighborhood of the parameter $a^{\alpha}=0$ gives

$$
\begin{aligned}
& x^{i^{*}}=x^{i}+\left.a^{\alpha} \frac{\partial f^{i}(x, a)}{\partial a^{\alpha}}\right|_{a=0}+O\left(\left(a^{\alpha}\right)^{2}\right), \alpha=1, \ldots, r, \\
& u^{k^{*}}=u^{k}+\left.a^{\alpha} \frac{\partial g^{k}(u, a)}{\partial a^{\alpha}}\right|_{a=0}+O\left(\left(a^{\alpha}\right)^{2}\right), \alpha=1, \ldots, r .
\end{aligned}
$$

The derivatives of $f^{i}$ and $g^{k}$ are smooth functions and are called infinitesimals of the group $G_{r}$ and denoted by $\xi_{\alpha}^{i}$ and $\eta_{\alpha}^{k}$.

Finding the Lie group of differential system (1) is equivalent to finding its infinitesimal operator(generator), thus we seek for the infinitesimal operators of $G_{r}$ in the following form

$$
X_{\alpha}=\xi_{\alpha}^{i}(x, u) \frac{\partial}{\partial x_{i}}+\eta_{\alpha}^{k}(x, u) \frac{\partial}{\partial u^{k}}, i=1, \ldots, n, k=1, \ldots, m, \alpha=1, \ldots, r .
$$

The set of tangent vectors to the manifold $G_{r}$ at the identity element $a=0$ is $\left\{X_{\alpha}, \alpha=1, \ldots, r\right\}$ and is a basis of the Lie algebra of the infinitesimal operators of $G_{r}$. The determination of the infinitesimal functions $\xi_{\alpha}^{i}$ and $\eta_{\alpha}^{k}$ states the group of transformations. By $X_{\alpha}$, one can determine the point transformations of the group $G_{r}$ by solving the Lie equations

$$
\frac{\partial f^{i}}{\partial a^{\alpha}}=\xi_{\alpha}^{i}(f), \frac{\partial g^{k}}{\partial a^{\alpha}}=\eta_{\alpha}^{k}(g), \alpha=1, \ldots, r, i=1, \ldots, n, k=1, \ldots, m
$$

with the initial conditions

$$
\left.f^{i}\right|_{a=0}=x^{i},\left.g^{k}\right|_{a=0}=u^{k} .
$$

These equations obtain a one-to-one correspondence between vector fields (2) and the group of transformations $G_{r}$. The Lie algebra vector field is prolonged to the derivatives in order to modify it with differential variables $u_{i}^{k}$,

$$
u_{i}^{k}=\frac{\partial u^{k}}{\partial x^{i}}, i=1, \ldots, n, k=1, \ldots, m .
$$

From that the extended infinitesimal operators are obtained as

$$
\widetilde{X}_{\alpha}=\xi^{i} \frac{\partial}{\partial x_{i}}+\eta^{k} \frac{\partial}{\partial u^{k}}+\zeta_{i}^{(1) k} \frac{\partial}{\partial u_{i}^{k}}+\cdots+\zeta_{i_{1} i_{2} \ldots i_{s}}^{(s) k} \frac{\partial}{\partial u_{i_{1} i_{2} \ldots i_{s}}^{k}} .
$$

Here we denote

$$
\zeta_{i}^{(1) k}=D_{i}\left(\eta^{k}\right)-u_{j}^{k} D_{i}\left(\xi^{j}\right)
$$

and

$$
\begin{gathered}
\zeta_{i_{1} i_{2} \ldots i_{s}}^{(s) k}=D_{i_{s}} \zeta_{i_{1} i_{2} \ldots i_{s-1}}^{(s-1) k}-u_{i_{1} i_{2} \ldots i_{s-1} j}^{k} D_{i_{s}}\left(\xi^{j}\right), \\
D_{i}=\frac{\partial}{\partial x_{i}}+u_{i}^{k} \frac{\partial}{\partial u^{k}}+u_{i j}^{k} \frac{\partial}{\partial u_{i j}^{k}}+\cdots+u_{i_{1} i_{2} \ldots i_{n}}^{k} \frac{\partial}{\partial u_{i_{1} i_{2} \ldots i_{n}}^{k}}+\cdots
\end{gathered}
$$

Theorem 1. [13] Let the Lie group of point transformations in the space of independent variables $\left(x, u, u_{1}, u_{2}, \ldots, u_{s}\right)$, dependent variables and all $s$-th order partial derivatives of dependent variables with respect to independent ones be $\tilde{G}_{r}$. Then system of differential equations (1) is invariant under the group $\tilde{G}_{r}$ if and only if

$$
\left.\tilde{X}_{\alpha} F_{\lambda}\left(x, u, u_{1}, u_{2}, \ldots, u_{s}\right)\right|_{(1)}=0, \lambda=1,2, \ldots, m .
$$

The invariance condition (4) is an overdetermined system of linear equations for the coordinates of infinitesimal operator (3) and is called the system of determining equations.

Now, let us introduce the Lie symmetry analysis of difference equations. The difference scheme for the solution of the system of differential equations (1) is denoted by

$$
H_{\lambda}(x, u, h, T u)=0, \lambda=1,2, \ldots, m .
$$


Here $h=\left(h_{1}, h_{2}, \ldots, h_{n}\right)$ is the mesh space vector and $T=\left(T_{1}, T_{2}, \ldots, T_{n}\right)$ represents the shift operator along the axis of the independent variables and given by

$$
T_{i}[u]\left(x_{1}, \ldots, x_{i}, \ldots, x_{n}\right)=u\left(x_{1}, \ldots, x_{i}+h_{i}, \ldots, x_{n}\right) .
$$

We denote a group of transformations in the space of mesh variables $(x, u, h)$ by $G_{r}^{h}$ and define as

$$
\begin{aligned}
& G_{r}^{h}=\left\{x^{i^{*}}=f^{i}(x, u, a) ; u^{k^{*}}=g^{k}(x, u, a) ; h^{i^{*}}\right\} \\
& =\varphi^{i}(x, u, h, a), i=1,2, \ldots, n, k=1,2, \ldots, m
\end{aligned}
$$

with the infinitesimal operator

$$
X_{\alpha}^{h}=X_{\alpha}+\varsigma_{\alpha}^{i}(x, u, h) \frac{\partial}{\partial h_{i}}, \alpha=1, \ldots, r
$$

Here

$$
\varsigma_{\alpha}^{i}=\frac{\partial \varphi^{i}}{\partial a^{\alpha}}, \alpha=1, \ldots, r
$$

In the space of differential and difference variables $\left(x, u, h, u_{1}, u_{2}, \ldots, u_{s}\right)$ the prolongation operator of the group of point transformations $\tilde{G}_{\alpha}^{(h)}$ is $\tilde{X}_{\alpha}^{(h)}$.

Theorem 2. [13] Finite difference scheme (5) is invariant under the group of transformations $\tilde{G}_{\alpha}^{(h)}$ if and only if

$$
\left.\tilde{X}_{\alpha}^{(h)} H_{\lambda}(x, u, h, T u)\right|_{(5)}=0, \lambda=1,2, \ldots, m .
$$

Symmetry analysis of the boundary value problem for PDEs

In this section we consider the Lie symmetry properties of BVPs. The invariance conditions under a group of point transformations of a BVP for a scalar PDE satisfy if the group separately leaves invariant the boundary conditions and the PDE of the BVP. The solution of the BVP resulting from the admitted point symmetry is an invariant solution if the BVP is well-posed. On the other hand, the concerned boundary conditions are in general not invariant under the symmetry of the considered PDEs. In view of this issue, one of the early definitions on the invariance of a BVP was given by G.W. Bluman [5].

Let us consider a $k$-th order $(k \geq 2)$ scalar PDE represented by

$$
F\left(x, u, \partial u, \partial^{2} u, \ldots, \partial^{k} u\right)=0 .
$$

Here $x=\left(x_{1}, x_{2}, \ldots, x_{n}\right)$ represents the coordinates corresponding to its $n$ independent variables, $u$ represents its dependent variable, and $\partial^{j} u$ represents the coordinates with components

$$
\partial^{j} u / \partial x_{i_{1}} \partial x_{i_{2}} \ldots \partial x_{i_{j}}=u_{i_{1} i_{2} \ldots i_{j}}, i_{j}=1,2, \ldots, n, j=1,2, \ldots, k
$$

corresponding to all $j$-th order partial derivatives of $u$ with respect to $x$.

We assume that PDE (6) can be written in the following form in terms of some specific component of the $l$-th order partial derivatives of $u$

$$
F\left(x, u, \partial u, \partial^{2} u, \ldots, \partial^{k} u\right)=u_{i_{1} i_{2} \ldots i_{l}}-f\left(x, u, \partial u, \partial^{2} u, \ldots, \partial^{k} u\right)=0,
$$

where $f\left(x, u, \partial u, \partial^{2} u, \ldots, \partial^{k} u\right)$ does not depend explicitly on $u_{i_{1} i_{2} \ldots i_{l}}$.

Now consider a BVP for PDE (7) defined on the domain $\Omega_{x}$ in $x$-space $\left[x=\left(x_{1}, x_{2}, \ldots, x_{n}\right)\right]$ with boundary conditions

described on boundary surfaces

$$
B_{a}\left(x, u, \partial u, \ldots, \partial^{k-1} u\right)=0
$$

$$
\omega_{a}(x)=0, a=1,2, \ldots, s .
$$

Let us assume that problem (7)-(9) has a unique solution. We use an infinitesimal generator as follows

$$
X=\xi_{i}(x) \frac{\partial}{\partial x_{i}}+\eta(x, u) \frac{\partial}{\partial u} .
$$

This infinitesimal generator defines a point symmetry acting on both $(x, u)$-space and on its projection to $x$-space. 
Definition 1. [5] The point symmetry $X$ in the form (10) is admitted by BVP (7)-(9) if and only if:

$1 X^{(k)} F\left(x, u, \partial u, \partial^{2} u, \ldots, \partial^{k} u\right)=0$ when $F\left(x, u, \partial u, \partial^{2} u, \ldots, \partial^{k} u\right)=0$.

$2 X \omega_{a}(x)=0$ when $\omega_{a}(x)=0, a=1,2, \ldots, s$.

$3 X^{(k-1)} B_{a}\left(x, u, \partial u, \ldots, \partial^{k-1} u\right)=0$ when $B_{a}\left(x, u, \partial u, \ldots, \partial^{k-1} u\right)=0$ on $\omega_{a}(x)=0, a=1,2, \ldots, s$.

The above definition does not apply for BVPs with free boundaries or with boundary conditions given at infinity. Therefore R. Chernica et al. (see [16], [17]) proposed a new invariance definition for BVPs which extends Bluman's definition to all possible boundary conditions. They formulated the definition of invariance for BVPs at operators of conditional symmetry case expressing what kind of transformations can be applied to transform boundary conditions at infinity to those containing no conditions at infinity. Consider a BVP for PDE (7) with boundary conditions (8) and conditions defined at infinity:

$$
\gamma_{c}(x)=\infty: \gamma_{c}\left(x, u, \partial u, \ldots, \partial^{k_{c}} u\right)=0, c=1,2, \ldots, p_{\infty},
$$

where $k_{c}<k$ and $p_{\infty}$ are given numbers and $\gamma_{c}(x)$ are specified functions that extend the domain on which the BVP is defined at infinity. We assume that all functions arising in (7), (8), (9), and (11) are given such that a classical solution of this BVP exists. Let us assume that the operator

$$
Q=\xi_{i}(x, u) \frac{\partial}{\partial x_{i}}+\eta(x, u) \frac{\partial}{\partial u}
$$

is a Q-conditional symmetry of PDE (7) satisfying the criterion:

$$
\left.Q^{(k)} F\left(x, u, \partial u, \partial^{2} u, \ldots, \partial^{k} u\right)\right|_{F\left(x, u, \partial u, \partial^{2} u, \ldots, \partial^{k} u\right)=0}=0,
$$

where $Q^{(k)}$ is the $k$-th prolongation of $Q$ and $Q(u)=0$ with $Q(u)=\xi_{i}(x, u) u_{x_{i}}-\eta(x, u)$. Let us consider the manifold for each $c=1,2, \ldots, p_{\infty}$ as

$$
M=\left\{\gamma_{c}(x)=\infty: \gamma_{c}\left(x, u, \partial u, \ldots, \partial^{k_{c}} u\right)=0\right\}
$$

in the extended space of variables $x, u, u_{x}, \ldots, u_{x}^{\left(k_{c}\right)}$. Suppose that there exists a smooth bijective transformation

$$
y=g(x), w=h(x, u),
$$

where $h(x, u)$ is a smooth function, $g(x)$ is a smooth vector function that maps the manifold $M$ into

$$
M^{*}=\left\{\gamma_{c}^{*}(y)=0: \gamma_{c}^{*}\left(y, u, \partial u, \ldots, \partial^{k_{c}^{*}} u\right)=0\right\}
$$

of the same dimensionality in the extended variable space $y, w, w_{y}, \ldots, w_{y}^{\left(k_{c}\right)}\left(k_{c}^{*} \leq k_{c}\right)$ and $y=y_{1}, \ldots, y_{n}$.

Definition 2. [17] BVPs (7), (8), and (11) are $Q$-conditionally invariant under operator (12) if:

1 Criterion (13) is satisfied;

$2 Q\left(\omega_{a}(x)\right)=0$ when $\omega_{a}(x)=0,\left.B_{a}\right|_{\omega_{a}(x)=0}=0, a=1, \ldots, s ;$

$3 Q^{(k)}\left(B_{a}\left(x, u, \partial u, \ldots, \partial^{k-1} u\right)\right)=0$ when $\omega_{a}(x)=0$ and $\left.B_{a}\right|_{\omega_{a}(x)=0}=0, a=1, \ldots, s$;

4 There exists a smooth bijective transform (14) mapping $M$ into $M^{*}$ of the same dimensionality;

$5 Q^{*}\left(\gamma_{c}^{*}(y)\right)=0$ when $\gamma_{c}^{*}(y)=0, c=1,2, \ldots, p_{\infty}$;

$6\left(Q^{*}\right)^{\left(k_{c}^{*}\right)}\left(\gamma_{c}^{*}\left(y, u, \partial u, \ldots, \partial^{k_{c}^{*}} u\right)\right)=0$ when $\gamma_{c}^{*}(y)=0$ and $\left.\gamma_{c}^{*}\right|_{\gamma_{c}^{*}(y)=0}=0, c=1,2, \ldots, r$.

This definition coincides with Definition 1 when $Q$ is a Lie symmetry operator and there is not any boundary condition defined at infinity.

\section{Lie symmetry analysis of the problem with sine-Gordon equation}

Let us consider the nonlinear hyperbolic problem for sine-Gordon equation

$$
\begin{gathered}
u_{t t}-u_{x x}=\sin u, t>0,-\infty<x<\infty, \\
u(0, x)=\varphi(x), \\
u_{t}(0, x)=\psi(x) .
\end{gathered}
$$


Equation (15) admits three-dimensional Lie group [8] spanned by the operators

$$
X_{1}=\frac{\partial}{\partial t}, X_{2}=\frac{\partial}{\partial x}, X_{3}=x \frac{\partial}{\partial t}+t \frac{\partial}{\partial x} .
$$

The operators generate one-parameter Lie groups

$$
\begin{gathered}
T_{1}: t^{*}=t+\epsilon_{1}, x^{*}=x, u^{*}=u, \\
T_{2}: t^{*}=t, x^{*}=x+\epsilon_{2}, u^{*}=u, \\
T_{3}: t^{*}=t+x \epsilon_{3}, x^{*}=x+t \epsilon_{3}, u^{*}=u,
\end{gathered}
$$

respectively. Since the group $T_{1}$ corresponds to translation on the variable $t$, the invariance of the boundary curve $t=0$ is not preserved. Thus BVP (15)-(17) is not invariant with respect to the group $T_{1}$. For the invariance of boundary condition (16) with respect to the symmetry group $T_{2}$, the equations

$$
\left.t^{*}\right|_{t=0}=0,\left.\left[u^{*}-\varphi\left(x^{*}\right)\right]\right|_{u-\varphi(x)=0}=0
$$

must be satisfied. The first equation of (18) is an identity, while the second equation results

$$
\varphi(x)=\varphi\left(x+\epsilon_{2}\right) .
$$

For the invariance of boundary condition (17) we need the first prolongation of the operator $X_{2}$. Using the prolongation formula for first-order derivatives

$$
\begin{aligned}
X^{(1)}=X & +\left(\eta_{t}+u_{t} \eta_{u}-u_{t}\left(\xi_{t}^{0}+u_{t} \xi_{u}^{0}\right)-u_{x}\left(\xi_{t}^{1}+u_{t} \xi_{u}^{1}\right)\right) \frac{\partial}{\partial u_{t}} \\
& +\left(\eta_{x}+u_{x} \eta_{u}-u_{t}\left(\xi_{x}^{0}+u_{x} \xi_{u}^{0}\right)-u_{x}\left(\xi_{x}^{1}+u_{x} \xi_{u}^{1}\right)\right) \frac{\partial}{\partial u_{x}},
\end{aligned}
$$

where $\xi^{0}, \xi^{1}$ are infinitesimals with respect to the variables $t$ and $x$ respectively, we get

$$
X_{2}^{(1)}=\frac{\partial}{\partial x} .
$$

Applying this operator to condition (17), we have

$$
\left.t^{*}\right|_{t=0}=0,\left.\left[u_{t}^{*}-\psi\left(x^{*}\right)\right]\right|_{u_{t}-\psi(x)=0}=0,
$$

which gives

$$
\psi(x)=\psi\left(x+\epsilon_{2}\right) .
$$

BVP (15)-(17) is invariant under the group of transformations $T_{2}$ if and only if equations (19) and (22) are satisfied. These equations result is that the functions $\varphi(x)$ and $\psi(x)$ are constant functions.

Following the same way, we obtain the invariance criterions of boundary condition (16) with respect to the symmetry group $T_{3}$ if the equations

$$
\begin{aligned}
t+x \epsilon_{3} & =0 \text { when } t=0, \\
u-\varphi\left(x+t \epsilon_{3}\right) & =0 \text { when } u-\varphi(x)=0
\end{aligned}
$$

are satisfied. The first equation results with $x=0$ or $\epsilon_{3}=0$ that gives the trivial group. Hence we arrive at boundary condition (16), which is invariant under the group of transformations $T_{3}$ with restriction

$$
x=0, \varphi(x)=\varphi\left(x+t \epsilon_{3}\right) .
$$

To examine invariance of boundary condition (17) we apply the first prolongation of the operator $X_{3}$ which is obtained from formula (20)

$$
X_{3}^{(1)}=x \frac{\partial}{\partial t}+t \frac{\partial}{\partial x}-u_{x} \frac{\partial}{\partial u_{t}}-u_{t} \frac{\partial}{\partial u_{x}}
$$


to (17) and we get

$$
x=0, \psi(x)-\psi\left(x+t \epsilon_{3}\right)=u_{x} \epsilon_{3} .
$$

Combining equations (23) and (25) we conclude that BVP (15)-(17) is invariant under the group of transformations $T_{3}$ with restriction $u_{x}(t, 0)=0$ and conditions:

(i) when $t=0$ the arbitrary functions are functions of $x$ variable only, such that $\varphi(x)$ and $\psi(x)$,

(ii) when $t \neq 0$ then the arbitrary functions $\varphi(x)$ and $\psi(x)$ are constant functions.

Considering all situations presented above, we infer that BVP (15)-(17) admits two-parameter Lie group $T_{2} \circ T_{3}$ that corresponds to symmetries $t^{*}=t+x \epsilon_{3}, x^{*}=x+t \epsilon_{3}+\epsilon_{2}, u^{*}=u$ if and only if $\varphi(x)$ and $\psi(x)$ are constant functions.

\section{Lie symmetry analysis of sine-Gordon equation in the difference scheme form}

In this section we study the Lie point symmetries of difference model for nonlinear problem (15)-(17). Before we proceed, let us present some preliminaries and notations about transformation groups and prolongations in the space of discrete variables given in [13]. We denote the sequence space $\left(x, u, u_{1}, u_{2}, \ldots\right)$ by $Z$ with

$$
\begin{gathered}
x=\left\{x^{i} \mid i=1,2, \ldots, n\right\}, \\
u=\left\{u^{k} \mid k=1,2, \ldots, m\right\} .
\end{gathered}
$$

We denote the set of $m n$ first partial derivatives as $u_{1}=\left\{u_{i}^{k}\right\}$, the set of second partial derivatives as $u_{2}=\left\{u_{i j}^{k}\right\}$, etc. The formulas for the derivatives when $n=2$ for $x=\left(x^{1}, x^{2}\right)$ are

$$
\begin{aligned}
& D_{1}=\frac{\partial}{\partial x^{1}}+u_{1} \frac{\partial}{\partial u}+u_{11} \frac{\partial}{\partial u_{1}}+u_{21} \frac{\partial}{\partial u_{2}}+\ldots, \\
& D_{2}=\frac{\partial}{\partial x^{2}}+u_{2} \frac{\partial}{\partial u}+u_{12} \frac{\partial}{\partial u_{1}}+u_{22} \frac{\partial}{\partial u_{2}}+\ldots,
\end{aligned}
$$

where

$$
u_{1}=\frac{\partial u}{\partial x^{1}}, u_{11}=\frac{\partial^{2} u}{\partial\left(x^{1}\right)^{2}}, u_{21}=\frac{\partial^{2} u}{\partial x^{2} \partial x^{1}}, \ldots
$$

In the proofs, for simplicity, the superscript $k$ on $u^{k}$ is omitted. The two commuting Taylor groups [18] with finite transformations $T_{a}^{1}=e^{a D_{1}}$ and $T_{a}^{2}=e^{a D_{2}}$ are generated by the given operators. In one dimensional case the new coordinates

$$
\begin{gathered}
x^{*}=T_{a}(x)=x+a, \\
u^{*}=T_{a}(u)=\sum_{s=0}^{\infty} \frac{a^{s}}{s !} u_{s}, \\
u_{1}^{*}=T_{a}\left(u_{1}\right)=\sum_{s=0}^{\infty} \frac{a^{s}}{s !} u_{s+1}, \\
\vdots \\
u_{k}^{*}=T_{a}\left(u_{k}\right)=\sum_{s=0}^{\infty} \frac{a^{s}}{s !} u_{s+k}
\end{gathered}
$$

are generated by the action of operator $T_{a}=e^{a D}$. Setting the arbitrary parameters $h_{1}, h_{2}>0$ the shift operators

$$
\begin{aligned}
& \underset{ \pm h}{S_{1}}=e^{ \pm h_{1} D_{1}} \equiv \sum_{s \geq 0} \frac{\left( \pm h_{1}\right)^{s}}{s !} D_{1}^{s}, \\
& \underset{ \pm h}{S_{2}}=e^{ \pm h_{2} D_{2}} \equiv \sum_{s \geq 0} \frac{\left( \pm h_{2}\right)^{s}}{s !} D_{2}^{s}
\end{aligned}
$$


are obtained. Using these shift operators, two discrete differentiation operators

$$
\underset{+h}{D_{i}}= \pm \frac{1}{h} \underset{ \pm h}{\left(S_{i}-1\right), i=1,2}
$$

are obtained. In the $\left(x^{1}, x^{2}\right)$-plane, the set of points

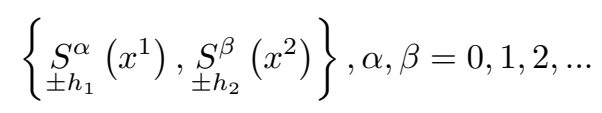

is called a uniform orthogonal difference mesh and denoted by $\omega_{h}$.

In two dimensional case with dependent variable $u$, independent variables $t, x$ and mesh variables $h_{1}, h_{2}$ we denote the spaces of differential variables, difference variables and the product of those spaces which is the space of sequences of power series by

$$
\begin{gathered}
\tilde{Z}=\left(t, x, u, u_{t}, u_{x}, u_{t x}, \ldots\right), \\
\underset{h}{Z}=\left(t, x, u, u_{t}, u_{x}, u_{t x}, \ldots, h_{1}, h_{2}\right), \\
\underset{h}{\tilde{Z}}=\left(t, x, u, u_{t}, u_{x}, \ldots, u_{h}, u_{h}, u_{t x}, \ldots, h_{1}, h_{2}\right),
\end{gathered}
$$

where

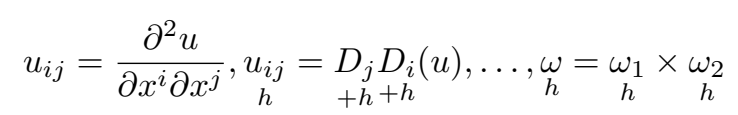

and $\omega_{i}$ is the difference mesh in the $i$-th direction, respectively.

Transformations in $\underset{h}{\tilde{Z}}$ is defined by the sequence of series with analytic coefficients,

$$
z^{j *}=\sum_{s \geq 0} A_{s}^{j}(z) a^{s}, A_{0}^{j}=z^{j},
$$

where $z^{j}$ is a coordinate of the vector $\left(t, x, u, u_{t}, u_{x}, \ldots, u_{h}, u_{h}, u_{t x}, \ldots\right)$ and these series form one-parameter groups generated by infinitesimal operators

$$
X=\xi^{t} \frac{\partial}{\partial t}+\xi^{x} \frac{\partial}{\partial x}+\eta^{k} \frac{\partial}{\partial u^{k}}+\sum_{s \geq 1} \zeta_{i_{1} i_{2} \ldots i_{s}} \frac{\partial}{\partial u_{i_{1} i_{2} \ldots i_{s}}}+\sum_{l \geq 1} \zeta_{i_{1} i_{2} \ldots i_{l}} \frac{\partial}{\partial u_{i_{1} i_{2} \ldots i_{l}}} .
$$

Prolongating the operator (26) for the variables $h_{1}$ and $h_{2}$ gives

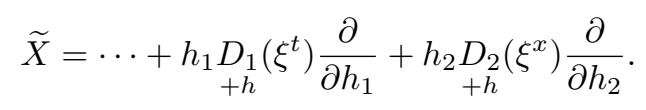

For first-order difference derivatives the coordinates of prolongation operator are given by the formulas

$$
\begin{aligned}
& \underset{h}{\zeta_{t}}=\underset{+h}{D_{1}}(\eta)-\underset{h+h}{u_{t} D_{1}}\left(\xi^{t}\right)-\underset{+h}{S_{1}}\left(u_{x}\right) \underset{+h}{D_{1}}\left(\xi^{x}\right), \\
& \underset{h}{\zeta_{x}}=\underset{+h}{D_{2}}(\eta)-\underset{+h}{S_{2}}\left(u_{t}\right) \underset{+h}{D_{2}}\left(\xi^{t}\right)-\underset{h+h}{u_{x} D_{2}}\left(\xi^{x}\right) .
\end{aligned}
$$

If the considered mesh is invariantly uniform or invariantly orthogonal, then the corresponding formulas for the invariant meshes must be satisfied in addition to prolongation formulas (27)-(28).

We presented the five-point difference scheme

$$
\frac{\hat{u}-2 u+\check{u}}{h_{1}^{2}}-\frac{u_{+}-2 u+u_{-}}{h_{2}^{2}}=\sin u
$$

for sine-Gordon equation (15) on the uniform and orthogonal mesh

$$
\hat{t}-2 t+\check{t}=0, x_{+}-2 x+x_{-}=0
$$


in our paper [3]. Here we denote mesh variables by $h_{1}, h_{2}$ and $\hat{t}=t+h_{1}, \check{t}=t-h_{1}, x_{+}=x+h_{2}$, $x_{-}=x-h_{2}, \hat{u}=u(\hat{t}, x), \check{u}=u(\breve{t}, x), u_{+}=u\left(t, x_{+}\right), u_{-}=u\left(t, x_{-}\right)$. We used the prolongation operator

$$
\begin{aligned}
\operatorname{pr} X & =\xi^{t} \frac{\partial}{\partial t}+\xi^{x} \frac{\partial}{\partial x}+\eta \frac{\partial}{\partial u}+\hat{\xi}^{t} \frac{\partial}{\partial \hat{t}}+\check{\xi} \frac{\partial}{\partial \check{t}}+\xi_{+}^{x} \frac{\partial}{\partial x_{+}} \\
& +\xi_{-}^{x} \frac{\partial}{\partial x_{-}}+\hat{\eta} \frac{\partial}{\partial \hat{u}}+\check{\eta} \frac{\partial}{\partial \check{u}}+\eta_{+} \frac{\partial}{\partial u_{+}}+\eta_{-} \frac{\partial}{\partial u_{-}}
\end{aligned}
$$

in the discrete subspace $\left(t, x, \hat{t}, \check{t}, x_{+}, x_{-}, u, \hat{u}, \check{u}, u_{+}, u_{-}\right)$and obtained three-parameter transformation group generated by the operators

$$
\begin{gathered}
X_{1}=\frac{\partial}{\partial t}+\frac{\partial}{\partial \hat{t}}+\frac{\partial}{\partial \check{t}}, X_{2}=\frac{\partial}{\partial x}+\frac{\partial}{\partial x_{+}}+\frac{\partial}{\partial x_{-}}, \\
X_{3}=x \frac{\partial}{\partial t}+t \frac{\partial}{\partial x}+x \frac{\partial}{\partial \hat{t}}+x \frac{\partial}{\partial \check{t}}+t \frac{\partial}{\partial x_{+}}+t \frac{\partial}{\partial x_{-}} .
\end{gathered}
$$

Difference equation (29) on the set of a finite number of points $\left(x_{n}^{k}, t_{n}^{k}\right)$ can be expressed as

$$
E_{1}: \frac{u_{n}^{k+1}-2 u_{n}^{k}+u_{n}^{k-1}}{h_{1}^{2}}-\frac{u_{n+1}^{k}-2 u_{n}^{k}+u_{n+1}^{k}}{h_{2}^{2}}=\sin u_{n}^{k}
$$

on the uniformly spaced orthogonal lattice

$$
\begin{aligned}
& E_{2}: t_{n}^{k+1}-t_{n}^{k}=h_{1}, E_{3}: x_{n}^{k+1}-x_{n}^{k}=0, \\
& E_{4}: t_{n+1}^{k}-t_{n}^{k}=0, E_{5}: x_{n+1}^{k}-x_{n}^{k}=h_{2} .
\end{aligned}
$$

D. Levi et al. mentioned certain independence criteria for difference schemes in two dimensional case [14]. By this criteria one can calculate the values of $(x, t, u)$ at all points beginning from the point $\left(x_{n}^{k}, t_{n}^{k}\right)$ and a given number of neighboring points and assures the existence of solution of the system. The following condition on the Jacobian

$$
|J|=\left|\frac{\partial\left(E_{1}, E_{2}, E_{3}, E_{4}, E_{5}\right)}{\partial\left(t_{n}^{k+1}, x_{n}^{k+1}, t_{n+1}^{k}, x_{n+1}^{k}, u_{n}^{k+1}\right)}\right| \neq 0
$$

is imposed by Levi et al. [14]. This condition allows to move upward and to the right along the curves passing through $\left(x_{n}^{k}, t_{n}^{k}\right)$ (with either $k$ or $n$ fixed). Difference scheme (30)-(32) satisfy certain independence criteria (33) by

$$
t_{n}^{k}=h_{1} k+t_{0}, x_{n}^{k}=h_{2} n+x_{0} .
$$

In this step, using difference equation (29) for the BVP (15)-(17), we write the difference problem

$$
\begin{gathered}
\frac{\hat{u}-2 u+\check{u}}{h_{1}^{2}}-\frac{u_{+}-2 u+u_{-}}{h_{2}^{2}}=\sin u, \\
u_{n}^{0}=\varphi^{h}(x), \\
\frac{\hat{u}_{n}^{1}-u_{n}^{0}}{\tau^{+}}=\psi^{h}(x) .
\end{gathered}
$$

In this paper the notation $\left(t, x, u, u_{h}, u_{h}, u_{t x}, \ldots, h_{1}, h_{2}\right)$ for difference variables in two-dimensional case is used for simplicity. Using these symbols, we rewrite the difference model (34)-(36) in the following form

$$
\begin{gathered}
u_{t t}-u_{x x}=\sin u, \\
u(0, x)=\varphi^{h}(x), \\
u_{h}(0, x)=\psi^{h}(x) .
\end{gathered}
$$

Difference equation (37) admits three-parameter groups generated by operators [3]

$$
X_{1}=\frac{\partial}{\partial t}, X_{2}=\frac{\partial}{\partial x}, X_{3}=x \frac{\partial}{\partial t}+t \frac{\partial}{\partial x} .
$$


Lie symmetry groups corresponding to the translation about time variable is described by the operator $X_{1}$, to the translation in space variable is described by the operator $X_{2}$, and to the rotation is described by the operator $X_{3}$. The difference scheme (37)-(39) does not admit symmetry group generated by $X_{1}$, because time translation violates invariance of the boundary surface $t=0$.

The invariance of boundary surface $t=0$ generated by the operator $X_{2}$ with respect to the transformation group is trivial. Under the symmetry of space translation $X_{2}$, boundary condition (38) is invariant if the equation

$$
u-\varphi^{h}\left(x+\epsilon_{2}\right)=0 \text { for } u-\varphi^{h}(x)=0
$$

is satisfied. From that it follows the condition

$$
\varphi^{h}(x)=\varphi^{h}\left(x+\epsilon_{2}\right)
$$

For the invariance of boundary condition (39) we require the first-order prolongation formulas in space of discrete variables. From (21) we know the coordinates for continuous derivatives in the prolongation of the operator $X_{2}$ are zero. Using formulas (27)-(28), we obtain the coordinates of first-order difference derivatives

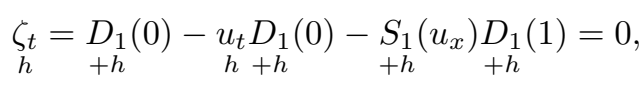

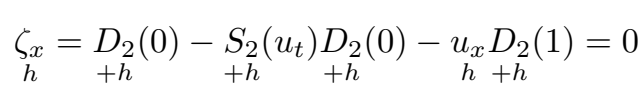

for the operator $X_{2}$ with $\eta=0, \xi^{t}=0, \xi^{x}=1$. In this case $X_{2}{ }^{(1)}=X_{2}$ where $X_{2}{ }^{(1)}$ is the first prolongation of the operator $X_{2}$ in discrete space. Applying this prolongation to condition (39) we get the criterion

$$
\psi^{h}(x)=\psi^{h}\left(x+\epsilon_{2}\right) .
$$

In consequence of combining criterions (41) and (42) one can say that difference scheme (37)-(39) is invariant with respect to the transformation group defined by the operator $X_{2}$ if and only if $\varphi^{h}(x)$ and $\psi^{h}(x)$ are constant functions. Using the same procedure, we obtain the invariance criterion of condition (38) under the rotation group spanned by the operator $X_{3}$ as

$$
t+x \epsilon_{3}=0 \text { when } t=0, u-\varphi^{h}\left(x+t \epsilon_{3}\right)=0 \text { when } u-\varphi^{h}(x)=0
$$

which results

$$
x=0, \varphi^{h}(x)=\varphi^{h}\left(x+t \epsilon_{3}\right) .
$$

Under the symmetry group generated by this operator we need to prolong operator (24) for the first-order difference derivatives in order to analyze invariance of condition (39). Substituting $\eta=0$, $\xi^{t}=x, \xi^{x}=t$ in the operator $X_{3}$ in $(27)-(28)$, we obtain the coefficients

$$
\underset{h}{\zeta_{t}}=-u_{x}, \zeta_{x}=-u_{t}
$$

and the prolongation operator

$$
\underset{h}{X_{3}(1)}=x \frac{\partial}{\partial t}+t \frac{\partial}{\partial x}-u_{x} \frac{\partial}{\partial u_{t}}-u_{t} \frac{\partial}{\partial u_{x}}-u_{x} \frac{\partial}{\partial u_{t}}-u_{t} \frac{\partial}{\partial u_{x}} .
$$

This operator generates the group $t^{*}=t+x \epsilon_{3}, x^{*}=x+t \epsilon_{3}, u^{*}=u, u_{t}^{*}=u_{t}-u_{x} \epsilon_{3}, u_{x}^{*}=u_{x}-u_{t} \epsilon_{3}$, $u_{t}^{*}=u_{h}-u_{x} \epsilon_{3}, u_{h}^{*}=u_{h}-u_{t} \epsilon_{3}$. Applying the operator to boundary condition (39) gives

$$
\begin{gathered}
t+x \epsilon_{3}=0 \text { for } t=0 \\
u_{t}-u_{x} \epsilon_{3}-\psi^{h}\left(x+t \epsilon_{3}\right)=0 \text { when } u_{h}-\psi^{h}(x)=0
\end{gathered}
$$

and consequently

$$
x=0, \psi^{h}(x)-\psi^{h}\left(x+t \epsilon_{3}\right)=u_{x} \epsilon_{3} .
$$

From equations (43) and (44) under the group of transformations $X_{3}$ and with the restriction $u_{x}(t, 0)=0$ we conclude that difference scheme (37)-(39) is invariant in two cases: 
(1) if $t=0$ for all arbitrary functions $\varphi^{h}(x)$ and $\psi^{h}(x)$,

(2) if $t \neq 0$ then $\varphi^{h}(x)$ and $\psi^{h}(x)$ are constant functions.

Remark. Note that in the prolongation operators ${\underset{h}{2}}_{2}^{(1)}$ and $X_{h}{ }^{(1)}$ we omit the coordinates for the mesh variables. Indeed, substituting the infinitesimals $\eta=0, \xi^{t}=0$ of the operator $X_{2} \underset{+h}{\operatorname{in}} \underset{+}{D_{1}}\left(\xi^{t}\right)$ and $\underset{+h}{D_{2}}\left(\xi^{x}\right)$ gives zero.

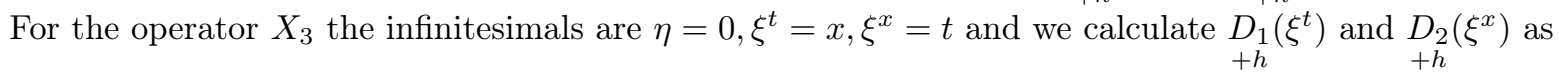

$$
\begin{aligned}
& \underset{+h}{D_{1}}(x)=\frac{1}{h}\left(S_{h}-1\right)=\left(D_{1}+\frac{h_{1}}{2 !} D_{1}^{2}+\cdots\right)(x)=0, \\
& D_{+h}(t)=\frac{1}{h} \underset{h}{\left(S_{2}-1\right)}=\left(D_{2}+\frac{h_{1}}{2 !} D_{2}^{2}+\cdots\right)(t)=0,
\end{aligned}
$$

where

$$
\begin{gathered}
D_{1}=\frac{\partial}{\partial t}+u_{t} \frac{\partial}{\partial u}+u_{t t} \frac{\partial}{\partial u_{t}}+u_{x t} \frac{\partial}{\partial u_{x}}+\ldots \\
D_{2}=\frac{\partial}{\partial x}+u_{x} \frac{\partial}{\partial u}+u_{t x} \frac{\partial}{\partial u_{t}}+u_{x x} \frac{\partial}{\partial u_{x}}+\ldots
\end{gathered}
$$

Conclusion

Some results discussed in this paper are as follows. We have investigated the BVP for sine-Gordon equation in differential and difference cases which are defined on an unbounded domain and lattice respectively. We obtain the invariance conditions for the problems under the group of transformations admitted by continuous and discrete sine-Gordon equation by applying the invariance definition in [16]. The transformations act on the difference scheme, lattices, and boundary conditions and preserve uniformity and orthogonality of the lattice. We used the prolongation formulas in discrete space which are formulated by Dorodnitsyn in [13] and analyze the invariance of the boundary conditions with derivative. On this basis we conclude that difference scheme (37)-(39) is invariant under the same restrictions of differential form (15)-(17) with respect to the symmetry groups generated by (40).

\section{References}

1 Rubinstein J. Sine-Gordon equation / J. Rubinstein // Journal of Mathematical Physics. - 1970. - 11. - No. 1. - P. 258-266.

2 Yildirim O. Weak solvability of the unconditionally stable difference scheme for the coupled sine-Gordon system / O. Yildirim, M. Uzun // Nonlinear Anal. Model. Control. - 2020. - 25. - P. 1-18.

3 Yildirim O. Lie point symmetries of difference equation for nonlinear sine-Gordon equation / O. Yildirim, S. Caglak // Physica Scripta. - 2019. - 94. - No. 085219. - P. 1-8.

4 Yildirim O. Symmetry analysis of the discrete nonlinear boundary value problems for the wave equation / O. Yildirim, S. Caglak // AIP Conference Proceedings. - 2019. - 2183. - 070029.

5 Bluman G.W. Symmetry and Integration Methods for Differential Equations / G.W. Bluman, S.C. Anco. - New York: Springer Verlag, 2002.

6 Bluman G.W. Symmetries and Differential equations / G.W. Bluman, S. Kumei. - Berlin: Springer, 1989.

7 Bluman G.W. Applications of the general similarity solution of the heat equation to boundary-value problems / G.W. Bluman // Quarterly of Applied Mathematics. - 1974. - 31. - No. 4. - P. 403-415.

8 Ibragimov N.H. CRC Handbook of Lie Group Analysis of Differential Equations. Vol. 1, ed. Ames, W.F. et al. / N.H. Ibragimov. - Boca Raton, FL: CRC Press, 1994.

9 Olver P.J. Applications of Lie Groups to Differential Equations. - New York: Springer, 1993.

10 Ovsiannikov L.V. Group Analysis of Differential Equations. 1(3). / L.V. Ovsiannikov. - New York: Academic Press, 1982.

11 Baumann G. Symmetry Analysis of Differential Equations with Mathematica / G. Baumann. - New York: Springer, 2000. 
12 Hydon P.E. Symmetry Methods for Differential Equations: A Beginner's Guide. Vol. 22. / P.E. Hydon. - London: Cambridge University Press, 2000.

13 Dorodnitsyn V.A. Applications of Lie Groups to Difference Equations. CRC Differential and Integral equations Series / V.A. Dorodnitsyn. - London: Chapman and Hall, 2011.

14 Levi D. Lie symmetries of multidimensional difference equations / D. Levi, S. Tremblay, P. Winternitz // Journal of Physics A: Mathematical and General. - 2001. - 34. - No. 44. - P. 9507.

15 Dorodnitsyn V. A heat transfer with a source: the complete set of invariant difference schemes / V. Dorodnitsyn, R. Kozlov // Journal of Nonlinear Mathematical Physics. - 2003. - 10. - No. 1. - P. 16-50.

16 Cherniha R. Lie symmetries of nonlinear boundary value problems / R. Cherniha, S. Kovalenko // Communications in Nonlinear Science and Numerical Simulation. - 2012. - 17. - No. 1. - P. 71-84.

17 Cherniha R. Lie and conditional symmetries of a class of nonlinear $(1+2)$-dimensional boundary value problems / R. Cherniha, J. King // Symmetry. - 2015. - 7. - No. 3. - P. 1410-1435.

18 Дородницын В.А. Группы преобразований в сеточных пространствах / В.А. Дородницын // Итоги науки и техники. Сер. Современные проблемы математики. Новые достижения. - 1989. - 34. C. $149-191$.

19 Пухначев В.В. Инвариантные решения уравнений Навье-Стокса, описывающие движения со свободной границей / В.В. Пухначев // Докл. АН СССР. - 1972. - 202. - № 2. - С. 302-305.

20 Andreev V.K. Applications of Group-Theoretical Methods in Hydrodynamics. Vol. 450. / V.K. Andreev, V. Kaptsov, V. Pukhnachev, A.A. Rodionov. - Netherlands: Springer, 1998.

21 Rogers C. (Eds.) Nonlinear boundary value problems in science and engineering. Vol. 183. / C. Rogers, W.F. Ames (Eds.) - New York: Academic Press, 1989.s

О. Йылдырым, С. Чаглак

Йылдыз техникалық, университеті, Стамбул, Түркия

\title{
Дифференциалдық және айырымдық теңдеулері үшін шеттік есептердегі Лидің симметриялары туралы
}

\begin{abstract}
Жалпы Ли топтары теориясының сипатына байланысты симметрияны талдау шеттік есептерге емес, жеке теңдеулерге қолданылады. Мақалада Лидің нүктелік симметриялар тобына қатысты синусГордон теңдеулері үшін шеттік есептер дифференциалдық және айырымдық түрлерінде алынды. Шеттік есептердің және олардың шешімдерінің инварианттық шарттары анықталған. Синус-Гордон теңдеуі үшін шеттік есепке сәйкес келетін айырымдық есептің инвариантты дискретизациясы зерттелді. Дифференциалдық жағдайда шексіз облыс, ал айырымдық жағдайда - жазықтықта орналасқан және барлық бағытта шекарасыз созылатын нүктелері бар тор қарастырылған.
\end{abstract}

Kiлm сөздер: симметрияны талдау, дербес туындылы теңдеулер, айырымдық теңдеулері, шеттік есептер.

\author{
О. Йылдырым, С. Чаглак
}

Технический университет Йылдыз, Стамбул, Турция

\section{О лиевских симметриях в краевых задачах для дифференциальных и разностных уравнений}

Ввиду природы теории групп Ли анализ симметрии применяется к отдельным уравнениям, а не к краевым задачам. В статье краевые задачи для уравнений синус-Гордон относительно группы точечных симметрий Ли получены как в дифференциальной, так и в разностной форме. Определены условия инвариантности краевых задач и их решений. Исследована инвариантная дискретизация разностной 
задачи, соответствующей краевой задаче для уравнения синус-Гордон. В дифференциальном случае рассмотрена неограниченная область, а в разностном - решетка с точками, лежащими в плоскости и тянущимися во всех направлениях без границ.

Ключевые слова: анализ симметрии, уравнения в частных производных, разностные уравнения, краевые задачи.

\section{References}

1 Rubinstein, J. (1970). Sine-Gordon equation. Journal of Mathematical Physics, 11(1), 258-266.

2 Yildirim, O., \& Uzun, M. (2020). Weak solvability of the unconditionally stable difference scheme for the coupled sine-Gordon system. Nonlinear Anal. Model. Control, 25, 1-18.

3 Yildirim, O., \& Caglak, S. (2019). Lie point symmetries of difference equation for nonlinear sine-Gordon equation. Physica Scripta, 94, 085219(8).

4 Yildirim, O., \& Caglak, S. (2019). Symmetry analysis of the discrete nonlinear boundary value problems for the wave equation. AIP Conference Proceedings, 2183, 070029.

5 Bluman, G.W., \& Anco, S.C. (2002). Symmetry and Integration Methods for Differential Equations. Springer Verlag, New York.

6 Bluman, G.W., \& Kumei, S. (1989). Symmetries and Differential Equations. Springer, Berlin.

7 Bluman, G.W. (1974). Applications of the general similarity solution of the heat equation to boundaryvalue problems. Quarterly of Applied Mathematics, 31(4), 403-415.

8 Ibragimov, N.H. (1994). CRC Handbook of Lie Group Analysis of Differential Equations. Vol. 1, ed Ames W.F. et al, CRC Press, Boca Raton, FL.

9 Olver, P.J. (1993). Applications of Lie Groups to Differential Equations. Springer, New York.

10 Ovsiannikov, L.V.E. (1982). Group Analysis of Differential Equations. 1(3), Academic Press, New York.

11 Baumann, G. (2000). Symmetry Analysis of Differential Equations with Mathematica. Springer, New York.

12 Hydon, P.E. (2000). Symmetry Methods for Differential Equations: A Beginner's Guide. Vol. 22, Cambridge University Press.

13 Dorodnitsyn, V.A. (2011). Applications of Lie Groups to Difference Equations. CRC Differential and Integral equations Series, Chapman and Hall, London.

14 Levi, D., Tremblay, S., \& Winternitz, P. (2001). Lie symmetries of multidimensional difference equations. Journal of Physics A: Mathematical and General, 34(44), 9507-9524.

15 Dorodnitsyn, V., \& Kozlov, R. (2003). A heat transfer with a source: the complete set of invariant difference schemes. Journal of Nonlinear Mathematical Physics, 10(1), 16-50.

16 Cherniha, R., \& Kovalenko, S. (2012). Lie symmetries of nonlinear boundary value problems. Communications in Nonlinear Science and Numerical Simulation, 17(1), 71-84.

17 Cherniha, R., \& King, J. (2015). Lie and conditional symmetries of a class of nonlinear (1+2)-dimensional boundary value problems. Symmetry, 7(3), 1410-1435.

18 Dorodnitsyn, V.A. (1991). Hruppy preobrazovanii v setochnykh prostranstvakh [Transformation groups in net spaces]. Itohi nauki i tekhniki. Seriia Sovremennye problemy matematiki. Novye dostizheniia Journal of Soviet Mathematics, 55(1), 1490-1517 [in Russian].

19 Pukhnachov, V.V. (1972). Invariantnye resheniia uravnenii Nave-Stoksa, opisyvaiushchie dvizheniia so svobodnoi granitsei [Invariant solutions of the Navier-Stokes equations describing motion with a free boundary]. Doklady AN SSSR - Reports of the USSR Academy of Sciences, 202(2), 302-305 [in Russian].

20 Andreev, V.K., Kaptsov, V., Pukhnachev, V., \& Rodionov, A.A. (1998). Applications of Group-Theoretical Methods in Hydrodynamics. Vol. 450, Springer, Netherlands.

21 Rogers, C., \& Ames, W. F. (Eds.) (1989). Nonlinear boundary value problems in science and engineering. Vol. 183, Academic Press. 